\title{
Integrating geography information system in teaching geography in Malaysian secondary smart schools
}

\author{
Soon Singh Bikar Singh ${ }^{1,2}$ \\ ${ }^{1}$ School of Education and Social Development, University Malaysia Sabah, Kota Kinabalu, Malaysia \\ ${ }^{2}$ School of Education, Macquarie University, Sydney, Australia
}

\section{Email address:}

Sohan4025@gmail.com(S. S. B. Singh)

\section{To cite this article:}

Soon Singh Bikar Singh. Integrating Geography Information System in Teaching Geography in Malaysian Secondary Smart Schools. Education Journal. Vol. 2, No. 4, 2013, pp. 149-154. doi: 10.11648/j.edu.20130204.17

\begin{abstract}
In 1996, Malaysia initiated a plan to make the country the Information and Communication Technology (ICT) hub of the region. To facilitate this, the government established the Multimedia Super Corridor (MSC) plan; this initiative is based on a belief that there will be growing demand for a computer-literate work force, as well as for professionals in ICT. As part of this initiative, the Malaysian Government also established the Smart School System in 1999. The Smart School Programme emphasises the use of technology tools as an important aid in learning and teaching: computers are the main instruction (teaching) tool. Significantly, the integration of ICT in teaching has given greater priority to Science, Mathematics, and English. Therefore, Geography has become what students perceive as a 'dry' subject with little use of technology. Unlike in Malaysia, in developed countriesGeography receives more attention and has become a key subject at both the primary and secondary level; as a result, Geographic Information Systems(GIS)are widely accepted and integrated intothe secondary and primary schoolGeography curriculum. However, the integration of GIS in Geography education in Malaysia is still regarded as a myth,for reasons of lack of ability, human resources, ground facilities, and ICT provision. Thus, this article will discuss the potential to integrate GIS in a Malaysian Secondary Smart School, which is well known for being the most sophisticated and well-equipped with ICT in the country. A content analysis was performed based on articles from local and foreign publications regarding the integration of GIS in Geography teaching. The content analyses, which include articles, theses and conference papers, discuss the opportunities to integrate GIS in teaching Geography. The analysis showsthat Secondary Smart Schools in Malaysia have adequate ICT facilities and well-trained human resourcesfor GIS. Thus, a plan for integrating GIS in Geography education is not a myth and will become a reality if the Malaysia Ministry of Education is ready to implement it.
\end{abstract}

Keywords: Geographic Information System (GIS), Secondary Smart School, Geography Curriculum

\section{Introduction}

The Malaysian Government established a Multimedia Super Corridor project in 1996, to build the country into a vast information communication and technology (ICT) hub of the region. In line with this, one of nine key strategies outlined in the Eighth Malaysia Plan (2001-2005) aims to develop a national ICT field and expand its use in all sectors of the economy. This initiative is based on the belief that there will be growing demand for a computer-literate workforce as well as professionals in ICT [1]. As part of this initiative, the Malaysian Government launched the Smart School Project in 1999 and the school computerisation programme in 2002. The main objective of this project is to emphasise the use of technology tools as an important aid in learning and teaching. Computers act as the main tools for instruction. However, the integration of ICT in teaching only provides greater priority to Bahasa Malaysia (Malay language), Science, Mathematics and English. In contrast, Geography remains a 'dry' subject with little use of technology and is taught with conventional teaching methods[2]

Unlike in Malaysia, in developed countries Geography receives more attention and has become a key subject at both the primary and secondary levels. As a result, beginning in the early 1990s, Geographic Information Systems (GIS)were widely accepted and implemented in the secondary school Geography curriculum. For example, the United Kingdom introduced GIS into teaching Geography in 1990[3]; the Netherlands adopted GIS in 2003 [4] and 
Turkey in 2005 [5]. However, the Malaysian Ministry of Education was not interested in integrating GIS in Geography education for reasons of lack of ability, human resources, and ICT facilities. Therefore, this study aimed to identify the strengths and weaknesses in an effort to integrate GIS in Geography teaching in Smart Schools, which are well-known for being the most complete schools with sophisticated ICT equipment in Malaysia.

\section{Methodology}

The study was conducted using the method of content analysis. The main focus of this study is to identify the im- portance of GIS andthe obstacles and the feasibility of integrating GIS in teaching Geography in Secondary Smart Schools in Malaysia. The content analysis method uses articles from local and foreign publications, including conference proceedings, journal articles, book chapters and theses discussions about the Geography curriculum reform, the Smart School system and Geography education, the importance of GIS and the opportunities to implement it in teaching Geography at Secondary Smart Schools in Malaysia. Each article chosen was examined thoroughly and was coded based on the six main themes (Table 1). Later, the identified themes with similar codes were listed together.

Table 1. Theme analysis for integrating GIS in Secondary Smart Schools in Malaysia

\begin{tabular}{|c|c|c|c|c|c|c|}
\hline Theme & Code & $\begin{array}{l}\text { Article } \\
\mathbf{J}\end{array}$ & $\mathbf{P}$ & $\mathbf{T}$ & B & Total \\
\hline $\begin{array}{l}\text { School Geography curriculum } \\
\text { reforms in Malaysia }\end{array}$ & $\begin{array}{l}\text { - Before world war } \\
\text { - After world war } \\
\text { - After independence } \\
\text { - The intergrated secondary school } \\
\text { curriculum }\end{array}$ & 1 & 1 & 4 & 6 & 12 \\
\hline $\begin{array}{l}\text { Smart School project in Malay- } \\
\text { sia and Geography education }\end{array}$ & $\begin{array}{l}\text { - History of Smart Schools in Ma- } \\
\text { laysia } \\
\text { - Facilities in Smart Schools }\end{array}$ & 3 & 4 & 1 & 8 & 16 \\
\hline $\begin{array}{l}\text { Integrated GIS in Geography } \\
\text { education }\end{array}$ & $\begin{array}{l}\text { - The idea of integrating GIS in } \\
\text { Geography education }\end{array}$ & 4 & 1 & 3 & 8 & 16 \\
\hline $\begin{array}{l}\text { The advantage of integrating } \\
\text { GIS in Malaysian Geography } \\
\text { education }\end{array}$ & $\begin{array}{l}\text { - Produce skilled workforce } \\
\text { - Motivation to learn Geography } \\
\text { - Enhanced achievement }\end{array}$ & 6 & & & 5 & 11 \\
\hline $\begin{array}{l}\text { Obstacles to integrating GIS in } \\
\text { Malaysian schools }\end{array}$ & $\begin{array}{l}\text { - Lack of computers in schools } \\
\text { - Electricity } \\
\text { - Lack of time to prepare lab } \\
\text { workand lesson plans } \\
\text { - Not incorporated in the school } \\
\text { curriculum } \\
\text { - Software }\end{array}$ & 8 & 5 & & 6 & 19 \\
\hline $\begin{array}{l}\text { Opportunities to integrate GIS } \\
\text { in Smart Schools }\end{array}$ & $\begin{array}{l}\text { - ICT infrastructure } \\
\text { - Human resources } \\
\text { - Geography curriculum } \\
\text { - GIS data }\end{array}$ & 5 & 1 & 4 & 10 & 20 \\
\hline Total & & 27 & 12 & 12 & 43 & 94 \\
\hline
\end{tabular}

$\mathrm{J}=$ Journal, $\mathrm{P}=$ Proceedings, $\mathrm{T}=$ Thesis, $\mathrm{B}=$ Book chapter

\section{Discussion}

\subsection{School Geography curriculum reforms in Malaysia}

The history of Geography education in Malaysia is unique. Geography as a subject was first introduced in Malay vernacular schools in 1927. The Geography curriculum was 'British Empire-centred' and students were taught map drawing and learned the chief towns, rivers, and industries in each country by the method of memorising facts. Geography education was officially introduced in primary and secondary English Schools in 1928. The curriculum emphasised more geographic terms, map reading, map drawing and geographic regions on five continents [6] 
According to [7], in 1936, Malay vernacular and English schools received their second curriculum to synchronise and structure to the standard of pupils' cognitive development and their experiences. However, Geography education in Malaysia halted during the period of the Second World War, during the Japanese occupation and the Malayan Emergency (1948-1960).

The Geographical education curriculum in Malaysia was reviewed again in 1956 by a committee which comprised teacher training college lecturers, educational administrators, and teachers. The primary school curriculum remained from the pre-war syllabus. On the other hand, secondary schools received greater attention through local geography, topographical map work, weather observations, and physical geography. A review of the effectiveness of the 1956 curriculum led to the 1964 Geography syllabus. It also emphasised logical progression and an introduction to both local and regional geography and map work. In 1979, primary school Geography was revised and drafted based on the concept of spatial organisation of geographical phenomena and societal pressure in a national context. At the same time, conceptual thinking of spatial orientation in Geography was introduced in lower secondary schools.

In line with national development and the vision to produce creative, innovative and knowledgeable human resources, Malaysia's Ministry of Education revamped the primary school curriculum in 1982. The new curriculum was introduced in schools in 1983 and provided greater emphasis on the acquisition of basic skills and knowledge through various learning activities [1]. Significantly, Geography as a discrete entity was eliminated and was integrated with Alam Dan Manusia(Local Studies) which was designed to integrate Science, History, Geography and Civic and Moral Studies. This subject was introduced in primary schools with Standard Four students.

The integrated secondary school curriculum was introduced in 1988 as a continuation of the curriculum changes introduced in the primary school. This new curriculum gave greater emphasis to the integration of teaching processes across the curriculum. These changes also influenced Geography in the secondary school context [2]. Geography became a compulsory subject for lower secondary school students, who were formally assessed in the government examination for Form 3 students (Penilaian Menengah Rendah). However, at the upper secondary school level (Forms 4 and Forms 5), Geography became an elective subject. As a result, fewer schools in Malaysia offer Geography at this level [8]. The same situation occurs at the pre-university level. Consequently, students in upper secondary school and at pre-university level have shied away from studying Geography [9].

\subsection{The Smart School Project in Malaysia and Geography Education}

For the past two decades, ICT components and multimedia-based learning have been widely applied in the class- room [10]. This has provided inspiration for the Malaysian Government to establishthe Smart School project (locally known as Sekolah Bestari). The main goal of this project is to provide more interactive teaching facilities and teaching materials to improve the teaching quality and student learning outcomes in schools [11]. A total of 89 schools were involved in a pilot programme [12]. There are three categories of Smart School in this project: new Smart Schools, state Smart Schools and remote Smart Schools.

The new Smart Schools are supplied with high-tech ICT equipment, state Smart Schools with a medium level and remote Smart Schools with a minimum level of technology and equipment. Each student in the new Smart Schools is provided with a personal laptop, while the Smart Schools in remote areas are supplied with a PC in the computer lab. The Malaysia Ministry of Education also provides laptops to all teachers involved in the pilot project, to facilitate and implement computer technology in the classroom [13]\&[14]. Various types of interactive learning material have been introduced into primary and secondary schools in Malaysia. This includes CD-ROM, browser-based teaching and learning materials, such as online tutorials available through web portals [15]. In line with this, the Malaysia Ministry of Education has collaborated with several private companies to develop interactive software.

Through this collaboration, the Malaysia Ministry of Education managed to develop 1,949 interactive coursework programs[14] However, the coursework developed only involved key learning subjects in the school such as Bahasa Melayu (Malay language), English, Science and Mathematics. Thus, it can be concluded that the introduction of the Smart School project in Malaysia did not have any positive impact on the curriculum and methods of teaching Geography in Malaysia: quite the reverse, Geography has become what students perceive to be a 'dry' subject with little use of technology [16].

\subsection{Integrated GIS in Geography Education}

GIS are information systems used to store, display, analyse and manipulate data related to space. Recognising the importance of GIS in Geography education, several developed countries around the world have taken innovative steps to incorporate GIS intothe primary and secondary Geography curriculum. According to [3],the United States was one of the first countries to use GIS in education. In 1990, the United Kingdom introduced GIS to the Geography curriculum [17] and fully utilised it to support the teaching of primary and secondary school students [18]. In 1998, Singapore also took initial steps to introduce GIS as an important tool for teaching Geography at the secondary school and junior college level. This was followed by the Netherlandsin 2003 and Turkey in 2005 [6].

In Malaysia, GIS is successfully used in various fields. These include areas such as engineering, environmental, crime mapping, real estate land use and politics. Most of the universities in Malaysia - namely, University Technol- 
ogy Malaysia (UTM), University Science Malaysia (USM), University Kebangsaan Malaysia (UKM), University Malaysia Sabah (UMS) and University Technology Mara (UITM) -use GIS widely in their research and offer it as a major subject to students. However, GIS has not been embraced by Malaysia's education system and it is absentfrom the Geography curriculum in the primary and secondary school contexts[8]. Nevertheless, researchers continue to explore its potential[2]. Most of the research is focused on the educational potential of GIS and the obstacles to its implementation; thus, it has inspired researchers to undertake research on integrating GIS into teaching Geography in the classroom. For instance, [19] Vasuhas conducted a study into using GIS in a local study, followed by [20]. Unfortunately, the findings of this research were not able to convince the Ministry of Education and Curriculum Department of Malaysia to embrace GIS within the Geography curriculum.

\subsection{The Advantages of Integrating GIS in Malaysian Geography Education}

GIS plays an important role in today's society. Thus, [21] emphasised that the integration of GIS in schools will produce a skilled workforce for spatial data analysis in the future. Therefore, the application of GIS to Geography education in Malaysia will produce the spatial data analysis expertise that will be needed by the country in the future [22]. In addition, studies conducted by[23], [24], [25] \& [26] showedthat GIS has positively influenced students' motivation to study Geography. The mostrecent research was by [5], using quasi-experimentswith primary school students in Turkey, and also reporting that GIS-supported lessons have a positive effect on students' motivation towards Geography lessons.

Furthermore, various studies conducted by scholars have shown that the use of GIS in geography teaching enhances students' achievements. For example, [18]reportedthat GIS teaching tools helped students to engage in more difficult tasks and enhancedtheir achievements. Similar findings were also reported by [17], [27] \& [28], also stating that not only can the use of GIS increase performance and motivate students to learn Geography, but it can also improve their concentration and thinking skills. Another study by [26]shows that GIS integrated lessons provideda more inductive learning environment in which students were able to access and make use of geospatial data to construct their understanding of Geography.

However, to date in Malaysia GIS is not integrated in Geography education. It is still under discussion and remains a distant milestone. At the same time, many local studies have reported that numbers of students in upper secondary school and at pre-university level are shying away from studying Geography. [9] argues that Geography is widely seen, by students, as a boring and difficult subject. This has resulted in students not being motivated to learn
Geography and the number of students studying Geography for the Malaysia Secondary School Certificate (SPM) and Higher School Certificate (STPM) has decreased. The situation becomes more critical as the percentages of students who pass both exams aredeclining each year [28]. Therefore, the primary advantage of integrating GIS in Geography education in Malaysia is that it will be able to enhance students' engagement and motivation to learn Geography.

\subsection{Obstacles to Integrating GIS in Malaysian Schools}

Various studies conducted abroad indicate that the main problems in integrating GIS in Geography education are: the lack of computers in schools;electricity supply[2];and lack of time to prepare lab work and lesson plans[29]. The same situation has occurred in Malaysia. For example, a study conducted by [9]in Sabah, Malaysia, showed that among the main obstacles to introducing GIS in schools is insufficient skills of accessing computers among teachers and students in secondary schools. In addition, [22] reported that the process of obtaining data that are appropriate to the current school Geography curriculum is a major problem in integrating GIS in Geography teaching in schools. Studies conducted by [8] also indicated that the main problem faced by teachers in integrating GIS in Geography teaching is that it is not incorporated in the school curriculum. In addition, prices of GIS software are expensive which hinders most schools in Malaysia in buying any. Moreover, the software available in the market is quite complex and difficult to learn. Thus, Geography teachers are unmotivated to learn and use GIS in their teaching practices [22].

\subsection{Opportunities to Integrate GIS in Smart Schools}

There are many opportunities to integrate GIS in Geography teaching and learning in Smart Schools. Most Smart Schools in Malaysia are equipped with high-tech equipment and computers[30]. This complete ICT infrastructure will facilitate teachers using GIS in their teaching. In addition, the construction of the self-access centre and digital resource centre in each of the Smart Schools gives students the opportunity to access and use web-based GIS outside school hours [19].

In 2003, the Malaysia Education Ministry implemented the Teaching Science and Mathematics in English (PPSMI) project to produce competent human resources equal with developing countries. To ensure the success of this programme, each schoolteacher was given special training to improve their ICT skills and knowledge. The introduction of the PPSMI programme at each school has helped increase the pre-ICT facilities, such as the computer lab and information technology equipment, in each of the Smart Schools in Malaysia. This programme has also succeeded in raising the standard of ICT literacy among teachers and students. Thus, the increasing number of teachersskilled in 
ICT is an important asset, which can be optimised for integrating GIS in Geography education.

Research by [29], [31] and [32] shows that the key factor preventing the implementation of GIS in Geography teaching is the lack of training and willingness of teachers to use GIS. However, this situation does not occur in Malaysia. The study conducted by Nordin [9] (2006) indicated that $94.1 \%$ of the 219 teachers in Sabah agreed and showed a positive sign for using GIS in their teaching. Moreover,as the present study by [33] on Smart Schools in Sabah indicated, $100 \%$ of young Geography teachers (with less than five years of teaching) have attended basic and advanced GIS courses in university. In addition, local universities that offer education courses require each Bachelor of $\mathrm{Ge}$ ography Education student to be enrolled in basic and advanced GIS courses as a condition of graduation. Therefore, GIS can be integrated into Smart Schools easily because there are sufficient well-trained teachers in GIS.

The study by [9] emphasises that GIS can be integrated in geographic education without having to modify the existing Geography curriculum; her study pointed out that part A (Local area study) of the secondary school Geography curriculum has the best chance of integrating GIS intogeography teaching. A study conducted by [34] also supports [19]'sfindings. [34] revealed that web-based GIS application is a suitable tool to teach the topics of human geography and physical geography without changing any part of the existing secondary school Geography curriculum. Tarmiji and Narimah [22] indicated that one of the obstacles to integrating GIS in Geography teaching is the lack of GIS data. However, this problem can be solved in Smart Schools, because with access to high-speed internet and equipped with sophisticated ICT equipment, Smart Schools can find, develop, and retain their own GIS data.

\section{Conclusion}

Geography education was first introduced in Malaysian schools in the days of British rule. Since then, the Geography education curriculum has been modified several times to be in line with the current National Education Philosophy and development of the country. The reformation of the primary and secondary school curriculum that occurred in 1983 and 1988 has had a significant impact on Geography education. At the same time, developed countries began integrating GIS into the primary and secondary school curriculum. In contrast, in Malaysia this is considered impossible and mythical because of a lack of ICT infrastructure and trained human resources. However, this study shows that most of the Smart Schools in Malaysia have efficient and sophisticated ICT facilities and, in addition, most Geography teachers in Smart Schools have attended GIS courses at university. Thus, there is a good chance ofintegrating GIS into the secondary school Geography curriculum. It will become a reality if the Malaysia Ministry of Education opens up opportunities.

\section{References}

[1] Lee, M. N. (2000). Education in Malaysia: towards vision 2020. School Effectiveness and School Improvement, 10 (1), 86-98

[2] Abdul Hamid Abdullah, Mohmadisa, Mohd Faris Dzianuddin, \& Muhamad Suhaily. (2006). Using GIS as teaching tool in geography education. In A. H. Abdullah (Eds.), Geographic education issues in Malaysia. Tanjung Malim: UPSI Publisher.

[3] Bednarz, S. W. (2004). Geographic information systems: A tool to support geography and environmental education? GeoJournal, 60 (2), 191-199

[4] Korevaar, W. v. d. S., J. (2004). Modern aardrijkskundeonderwijs met GIS op de kaartgezet [Modern geography education using GIS has been put on the map], Geografie[Geography], 13 (9), 44-46.

[5] Aladag, E. (2010). The effects of GIS on students' academic achievement and motivation in seventh grade social studies lessons In Turkey. International Research in Geographical and Environmental Education, 19 (1), 11-23.

[6] Chew, T. Y. (1977). Planning in education. In F. H. Wong (Ed.), Reading In Malaysian Education (pp. 243). Kuala Lumpur: University Malaya.

[7] Khalid, K. (1989). Curriculum change and innovation: A study in the teaching of secondary school geography in Malaysia.(Doctoral dissertation). Columbia University. New York.

[8] Latih, H., \& Vasugiammai, M. (2010). ICT implementation among Malaysian schools: GIS, obstacles and opportunities. Procedia-Social and Behavioral Sciences, 2(2), 2846-2850.

[9] Nordin Sakke. (2006). Implementation of GIS in geography education in Sabah. Environmental Geography and Education (pp. 109-122). Tajung Malim: UPSI.

[10] Beuschel, W., Graiser, B., \& Draheim, S. (2003). Communication needs of online students. In A.K. Aggarwal, Web-based education: Learning from experience (pp. 203-222). Hershey: Idea Group.

[11] Malaysia Ministry of Education. (2006). User acceptance and effectiveness of the Smart School integrated solution. Kuala Lumpur: Educational Technology Division.

[12] Malaysia Ministry of Education. (2008). National report: Education in Malaysia. Kuala Lumpur: Ministry of Education.

[13] Rahimah, H. A. (1998). Educational development and reformation in Malaysia: past, present and future. Journal of Educational Administration, 36 (5), 462-475

[14] Malaysia Ministry of Education. (2004). Conceptual blueprints - A smart school flagship application. Kuala Lumpur: Ministry of Education. Retrieved, from http://www.msc.com.my/smartschool.

[15] Azizah Ya'acob \& Hanita Azman.(2005). Implementation of the Malaysian Smart School: An Investigation of Teaching-Learning Practices and Teacher-Student Readiness. Journal of e-Learning, 2 (2), 16-25. 
[16] Latih, H., \& Vasugiammai, M. (2011). Technology integrated teaching in Malaysian schools: GIS, a SWOT analysis. World Journal of Educational Technology, 3 (2), 64-74

[17] Wiegand, P. (2003). School students' understanding of choropleth maps: Evidence from collaborative map making using GIS. Journal of Geography, 102 (6), 234-242.

[18] Fargher, M. (2012). United Kingdom: Realizing the potential for GIS in the school geography curriculum. In Milson A.J, Demirci. A \& Kerski. J (Eds.), International Perspectives on Teaching and Learning with GIS in Secondary Schools. ( pp. 299-304).

[19] Vasugiammai, M. (2005). GIS in Malaysian School : GIS Application in Local Studies. (Master's thesis), University Sains Malaysia. Penang. Malaysia.

[20] Umah Devi, R. (2008). Open source GIS in Teaching and Learning Geography in Schools. (Masters' thesis), University Sains Malaysia. Penang. Malaysia.

[21] Lam, C.-C., Li, E., \& Wong, J. (2009). Implementation of geographic information system (GIS) in secondary geography curriculum in Hong Kong: current situations and future directions 1. International Research in Geographical and Environmental Education, 18 (1), 57-74.

[22] Tarmiji Masron \& Narimah Samat. (2009). GIS in School. Kuala Lumpur: Prentice Hall.

[23] Keiper, T. (1996). Introducing a GIS to an elementaryclassroom : A case study (Doctoral dissertation). University of Missouri, Columbia.

[24] Keiper, T. A. (2000). GIS for elementary students: An inquiry into a new approach to learning geography. Journal of Geography, 98 (2), 47-59.

[25] West, B. A. (2003). Student attitudes and the impact of GIS on thinking skills and motivation. Journal of Geography, $102(6), 267-274$

[26] Milson, A. J., \& Earle, B. D. (2008). Internet-based GIS in an inductive learning environment: A case study of ninth-grade geography students. Journal of Geography, 106 (6), 227-237.
[27] Shin, E. K. (2006). Using geographic information systems (GIS) to improve fourth graders' geographic content knowledge and map skills. Journal of Geography, 105 (3), 109-120.

[28] Sharifah Norsana. (2006). Geography education in pre university level in Malaysia. In A. Hamid (Ed.), Geographic Education Issuess in Malaysia. Tanjung Malim: UPSI Publisher

[29] Demirci, A., \& Karaburun, A. (2009). How to make GIS a common educational tool in schools: Potentials and implications of the GIS for teachers book for geography education in Turkey. Ozean Journal of Applied Sciences, 2(2), 205-215.

[30] Malaysia Ministry of Education. (2004). Smart School Pilot Project Information. Kuala Lumpur: Ministry of Education. Retrieved from http://www.moe.edu.my/bestraiNET/bestarinet2004.htm

[31] Milson, A. J., \& Kerski, J. J. (2012). Around the World with Geospatial Technologies. Social Education, 76(2), 105-108.

[32] Eksteen, S., Pretorius, E., \& Breetzke, G. (2012). South Africa: Teaching Geography with GIS Across Diverse Technological Contexts In J. M. Andrew, D. Ali \& J. K. Joseph (Eds.), International Perspectives On Teaching And Learning with GIS In Secondary School (pp. 225-232). London: Springer.

[33] Singh, S. S. B., Kleeman, G., \& Van Bergen, P. (2012). Opportunities to Implement GIS in Teaching and Learning Geography: A Survey Among Smart Schools in Sabah, Malaysia. Procedia-Social and Behavioral Sciences, 69, 884-889.

[34] Rosilawati, N., Syra, Goh, Tan. (2011). Empowering teaching and learning of geography by using web-based GIS application as a teaching tool. Paper presented at the International Education Technology Conference, Istanbul. 